\title{
Interactions Between Barley Grain Processing and Source of Supplemental Dietary Fat on Nitrogen Metabolism and Urea-Nitrogen Recycling in Dairy Cows
}

\author{
G. N. Gozho, M. R. Hobin, and T. Mutsvangwa ${ }^{1}$ \\ Department of Animal and Poultry Science, University of Saskatchewan, Saskatoon, Canada S7N 5A8
}

\begin{abstract}
The objective of this study was to determine the effects of methods of barley grain processing and source of supplemental fat on urea-N transfer to the gastrointestinal tract (GIT) and the utilization of this recycled urea-N in lactating dairy cows. Four ruminally cannulated Holstein cows $(656.3 \pm 27.7 \mathrm{~kg}$ of BW; $79.8 \pm 12.3$ $\mathrm{d}$ in milk) were used in a $4 \times 4$ Latin square design with 28 -d periods and a $2 \times 2$ factorial arrangement of dietary treatments. Experimental diets contained dryrolled barley or pelleted barley in combination with whole canola or whole flaxseed as supplemental fat sources. Nitrogen balance was measured from d 15 to 19 , with concurrent measurements of urea-N kinetics using continuous intrajugular infusions of $\left[{ }^{15} \mathrm{~N}^{15} \mathrm{~N}\right]-$ urea. Dry matter intake and $\mathrm{N}$ intake were higher in cows fed dry-rolled barley compared with those fed pelleted barley. Nitrogen retention was not affected by diet, but fecal $\mathrm{N}$ excretion was higher in cows fed dryrolled barley than in those fed pelleted barley. Actual and energy-corrected milk yield were not affected by diet. Milk fat content and milk fat yield were higher in cows fed dry-rolled barley compared with those fed pelleted barley. Source of supplemental fat did not affect urea-N kinetics. Urea-N production was higher (442.2 vs. $334.3 \mathrm{~g}$ of $\mathrm{N} / \mathrm{d}$ ), and urea-N entering the GIT tended to be higher (272.9 vs. $202.0 \mathrm{~g}$ of $\mathrm{N} / \mathrm{d}$ ), in cows fed dry-rolled barley compared with those fed pelleted barley. The amount of urea-N entry into the GIT that was returned to the ornithine cycle was higher (204.1 vs. $159.5 \mathrm{~g}$ of $\mathrm{N} / \mathrm{d}$ ) in cows fed dry-rolled barley than in pelleted barley-fed cows. The amount of urea-N recycled to the GIT and used for anabolic purposes, and the amounts lost in the urine or feces were not affected by dietary treatment. Microbial nonammonia N supply, estimated using total urinary excretion of purine derivatives, was not affected by diet. These results show that
\end{abstract}

Received June 1, 2007.

Accepted October 1, 2007.

${ }^{1}$ Corresponding author: tim.mutsvan@usask.ca even though barley grain processing altered urea-N entry into the GIT, the utilization of this recycled urea$\mathrm{N}$ for microbial production was unaffected as the additional urea-N, which entered the GIT was returned to ureagenesis.

Key words: dairy cow, nitrogen metabolism, supplemental dietary fat, processed barley

\section{INTRODUCTION}

Under a wide variety of dietary conditions and productive states in ruminants, hepatic urea-N output often exceeds apparent digestible $\mathrm{N}$ intake (Lapierre and Lobley, 2001). However, animals still maintain a positive $\mathrm{N}$ balance primarily by recycling between 40 and $80 \%$ of their hepatic urea-N output to the gastrointestinal tract (GIT), particularly the rumen. Estimates indicate that 35 to $55 \%$ of the recycled urea-N can potentially be used for microbial protein production, thereby contributing to the metabolizable protein requirements of the host animal (Lapierre and Lobley, 2001). The proportion of hepatic urea-N output that can be returned to the GIT depends upon the concentration of ammonia in the rumen fluid, the extent of ruminal fermentation of organic matter, and plasma urea concentration (Kennedy and Milligan, 1980; Huntington, 1989; Hettiarachchi et al., 1999). Therefore, dietary manipulation such as increasing the amounts of ruminally fermentable carbohydrate (Kennedy and Milligan, 1980; Huntington, 1989; Rémond et al., 1996), or grain processing such as steam flaking that shifts carbohydrate digestion from the small intestine to the rumen (Theurer et al., 2002) can potentially increase urea-N transfer to the rumen and enhance microbial protein synthesis.

Fat supplement sources such as oilseeds, are commonly added to ruminant diets to increase caloric density and to enhance the proportions of desirable unsaturated fatty acids in edible products (Raes et al., 2004). In general, as the degree of unsaturation of fats in these supplements increases, inhibitory effects on ruminal bacterial growth also increase (Jenkins, 1993). How- 
ever, fat supplements do not decrease microbial $\mathrm{N}$ flow to the duodenum (Clark et al., 1992; Stern et al., 1994), due to an increase in the efficiency of ruminal bacterial protein synthesis associated with increased degree of unsaturation of dietary fat (Pantoja et al., 1994; Oldick and Firkins, 2000). It has been suggested that the increased ruminal bacterial efficiency when supplemental fat sources that contain unsaturated fat are fed is due to the decline in protozoal counts that leads to decreased intraruminal bacterial recycling (Clark et al., 1992; Jenkins, 1993). It is possible that the mechanism related to the positive effects of unsaturated dietary fat on ruminal bacterial efficiency may result from an increased urea-N transfer from blood into the rumen, leading to greater capture and incorporation into bacterial cells. Reduced ruminal protozoal counts are consistently associated with decreased ruminal ammonia-N $\left(\mathrm{NH}_{3}-\mathrm{N}\right)$ concentrations (Jouany, 1996). Ruminal $\mathrm{NH}_{3}$ $\mathrm{N}$ concentration is negatively correlated with the rate of urea-N transfer into the rumen (Kennedy and Milligan, 1980), possibly because high ruminal $\mathrm{NH}_{3}-\mathrm{N}$ concentration decreases the ruminal epithelium's permeability to urea (Egan et al., 1986). Therefore, it is possible that adding unsaturated fat supplements in the diet decreases ruminal $\mathrm{NH}_{3}-\mathrm{N}$ concentration and increases urea-N transfer from blood into the rumen.

Limited information is available on how concomitant changes in dietary content of ruminally fermentable carbohydrate and source of supplemental dietary fat might influence urea-N kinetics in dairy cows. We hypothesized that adding supplemental fat sources that varied in their degree of unsaturation would alter the amount of urea-N transferred to the GIT. We further postulated that processing barley grain by dry-rolling or pelleting would alter the supply of ruminally fermentable carbohydrate and, thus, affect the amount of urea-N that is captured and used for microbial synthesis. Therefore, the primary objective of this study was to determine how interactions between method of barley grain processing (dry-rolling vs. pelleting) and source of supplemental fat in the diet (whole canola seed vs. whole flaxseed) alter urea-N transfer to the GIT and its utilization in lactating dairy cows.

\section{MATERIALS AND METHODS}

\section{Animals and Experimental Design}

Four Holstein cows $(656.3 \pm 27.7 \mathrm{~kg}$ of BW; $79.8 \pm$ 12.3 DIM) were used in a $4 \times 4$ Latin square design with 28 -d periods and a $2 \times 2$ factorial arrangement of dietary treatments. Each experimental period consisted of $14 \mathrm{~d}$ of dietary adaptation and $14 \mathrm{~d}$ of data collection. Throughout the experiment, cows were housed individually in tie-stalls at the Greenbrae Dairy Research Fa- cility (University of Saskatchewan). Cows were cared for and handled in accordance with the Canadian Council of Animal Care regulations, and their use in the experiment was approved by the University of Saskatchewan Animal Care Committee (UCACS Protocol No. 20040048).

\section{Experimental Treatments and Feeding Management}

Experimental treatments were combinations of barley grain processing (dry-rolling or pelleting) and 2 sources of dietary supplemental fat (whole canola seed and whole flaxseed) as follows: a) dry-rolled barley + whole canola seed, b) dry-rolled barley + whole flaxseed, c) pelleted barley + whole canola seed, and d) pelleted barley + whole flaxseed. The diets were formulated to be isonitrogenous and isolipidic. Complete ingredient and chemical composition of experimental diets are presented in Table 1. Dry-rolled barley was prepared by passing whole barley grain through large rollers $(23 \times$ $58 \mathrm{~cm})$. For pelleting, whole barley grain was ground through a $6.25-\mathrm{mm}$ screen in a hammer-mill and then pelleted using a California pellet mill. Both dry-rolled and pelleted barley were from the same source. Experimental diets were fed twice daily at 0900 and $1600 \mathrm{~h}$ as TMR for ad libitum intake. The forage:concentrate ratio of the TMR was 50:50. The forage component of the TMR was a mixture of barley silage and chopped alfalfa hay. Barley silage contained $35.5 \% \mathrm{DM}$, and its chemical composition (DM basis) was OM, 90.9\%; CP, $11.3 \%$; NDF, $54.7 \%$; ADF, $35.8 \%$; and EE, $3.42 \%$. Whole canola seed or whole flaxseed was added such that experimental TMR contained approximately 5.3\% total fat.

\section{Sample Collection}

During the 14-d data collection period (d 15 to 28), feed intake was recorded daily, TMR samples were collected 3 times weekly, and orts were collected daily and composited by cow proportionally to the weight of feed refused each day and stored at $-20^{\circ} \mathrm{C}$ for later analysis. Cows were milked twice daily at 0500 and $1500 \mathrm{~h}$, and milk weights were recorded during the 14-d data collection period. Milk samples were collected into plastic vials with 2-bromo-2-nitropropane-1-2-diol as a preservative on $\mathrm{d} 23,25$, and 26 from morning and afternoon milking. Daily milk samples from the 2 milkings for each cow were pooled based on milk yield from each milking. Pooled milk samples were sent to the Provincial Milk Testing Laboratory (Saskatchewan Agriculture, Food and Rural Revitalization, Regina, SK) for milk protein and fat analyses using a near infrared analyzer (Foss System 4000, Foss Electric, Hillerød, Denmark) according to AOAC (1990). 
Table 1. Ingredient and chemical composition of TMR with dry-rolled or pelleted barley containing canola or flax as supplemental fat sources

\begin{tabular}{|c|c|c|c|c|}
\hline \multirow[b]{2}{*}{ Item } & \multicolumn{2}{|c|}{ Canola } & \multicolumn{2}{|c|}{ Flax } \\
\hline & $\begin{array}{c}\text { Dry-rolled } \\
\text { barley }\end{array}$ & $\begin{array}{c}\text { Pelleted } \\
\text { barley }\end{array}$ & $\begin{array}{c}\text { Dry-rolled } \\
\text { barley }\end{array}$ & $\begin{array}{c}\text { Pelleted } \\
\text { barley }\end{array}$ \\
\hline \multicolumn{5}{|l|}{ Ingredients, \% DM } \\
\hline Barley silage & 32.46 & 32.46 & 32.48 & 32.48 \\
\hline Alfalfa hay & 17.24 & 17.24 & 17.26 & 17.26 \\
\hline Barley grain & 29.81 & 29.81 & 29.39 & 29.39 \\
\hline Canola seed & 8.13 & 8.13 & - & - \\
\hline Flaxseed & - & - & 8.30 & 8.30 \\
\hline Soybean meal & 3.55 & 3.55 & 3.75 & 3.75 \\
\hline Molasses & 0.40 & 0.40 & 0.40 & 0.40 \\
\hline Canola meal & 3.49 & 3.49 & 3.49 & 3.49 \\
\hline Corn gluten meal & 0.96 & 0.96 & 0.96 & 0.96 \\
\hline Wheat dried distillers grains & 1.78 & 1.78 & 1.78 & 1.78 \\
\hline Dynamate $^{1}$ & 0.18 & 0.18 & 0.18 & 0.18 \\
\hline Salt, $\mathrm{CoI}^{2}$ & 0.33 & 0.33 & 0.33 & 0.33 \\
\hline Mineral-vitamin supplement ${ }^{3}$ & 1.66 & 1.66 & 1.66 & 1.66 \\
\hline \multicolumn{5}{|l|}{ Chemical composition } \\
\hline $\mathrm{DM}, \%$ & 57.47 & 58.31 & 57.37 & 58.76 \\
\hline Starch, \% of DM & 22.96 & 22.64 & 24.69 & 23.73 \\
\hline $\mathrm{CP}, \%$ of $\mathrm{DM}$ & 17.42 & 17.31 & 17.19 & 17.00 \\
\hline $\mathrm{NDF}, \%$ of DM & 34.75 & 35.21 & 34.77 & 34.73 \\
\hline $\mathrm{ADF}, \%$ of $\mathrm{DM}$ & 21.04 & 21.37 & 21.00 & 20.85 \\
\hline Crude fat, $\%$ of DM & 5.32 & 5.33 & 5.24 & 5.29 \\
\hline
\end{tabular}

On d 14 of each experimental period, cows were fitted with temporary vinyl catheters $(0.86 \mathrm{~mm}$ inside diameter $\times 1.32 \mathrm{~mm}$ outside diameter; Scientific Commodities Inc., Lake Havasu City, AZ) in the right and left jugular veins to allow for simultaneous isotope infusion and blood sampling. Urea-N transfer to the GIT and wholebody $\mathrm{N}$ balance were determined between $\mathrm{d} 15$ and 19 as described by Lobley et al. (2000), except that urine was collected using bladder catheters. Briefly, background samples of urine and feces were collected on $d$ 14 to measure ${ }^{15} \mathrm{~N}$ natural abundance. Starting on d 15, double-labeled urea $\left(\left[{ }^{15} \mathrm{~N}^{15} \mathrm{~N}\right]\right.$-urea, 99.8 atom $\%{ }^{15} \mathrm{~N}$; Cambridge Isotope Laboratories, Andover, MA) prepared in $0.15 \mathrm{M}$ sterile saline was infused continuously into the jugular vein at a rate of $0.384 \mathrm{~g} / \mathrm{d}$ for $96 \mathrm{~h}$. Total collection of feces and urine were conducted between d 15 and 19 of each experimental period. Feces were collected into large steel trays, which were positioned over the gutter behind each stall. Daily fecal output for each cow was determined by weighing and feces were then mixed thoroughly before $2.5 \%$ of daily output was sampled and stored at $-20^{\circ} \mathrm{C}$ for later chemical analysis. During isotope infusion, fecal grab samples were collected daily at $0900 \mathrm{~h}$ just before the morning feeding and stored at $-20^{\circ} \mathrm{C}$ until analyzed for ${ }^{15} \mathrm{~N}$ enrichment.
Total urine output was collected using indwelling Bardex Foley bladder catheters (26 Fr, 75-cc ribbed balloon, lubricious-coated; C. R. Bard Inc., Covington, GA). Catheters were inserted at $0900 \mathrm{~h}$ on $\mathrm{d} 14$ and were then connected to urine collection tubing when isotopic infusions were initiated at $0900 \mathrm{~h}$ on $\mathrm{d} 15$. Urine was collected into 20-L Carboy polyethylene containers into which $150 \mathrm{~mL}$ of concentrated $\mathrm{HCl}$ had been added to achieve urine $\mathrm{pH}$ of less than 3 . The acidification of urine was necessary to prevent microbial degradation and the loss of volatile $\mathrm{NH}_{3}-\mathrm{N}$. Daily urinary output was weighed, mixed thoroughly, and a 5\% subsample of the daily output was drawn, pooled for each cow during each collection period and stored at $-20^{\circ} \mathrm{C}$ until analyzed for total N. A 50-mL sample of urine was also collected daily during isotope infusion directly from the urine collection tubing and stored at $-20^{\circ} \mathrm{C}$ until analyzed for proportions of $\left[{ }^{15} \mathrm{~N}^{15} \mathrm{~N}\right]-, \quad\left[{ }^{14} \mathrm{~N}^{15} \mathrm{~N}\right]-$, and $\left[{ }^{14} \mathrm{~N}^{14} \mathrm{~N}\right]$-urea. In addition, a 2-mL aliquot of urine was diluted with $8 \mathrm{~mL}$ of distilled water and stored at $-20^{\circ} \mathrm{C}$ for later determination of urea- $\mathrm{N}$ and purine derivatives. Blood samples were collected daily during isotope infusion from the contralateral jugular vein into sodium heparin-coated tubes just before the morning feeding. Blood samples were centrifuged at $1,500 \times g$ for $15 \mathrm{~min}$ 
at $4^{\circ} \mathrm{C}$ and the plasma obtained was stored at $-20^{\circ} \mathrm{C}$ until later analysis for urea-N.

Starting on d 23 of each experimental period, ruminal $\mathrm{pH}$ was measured continuously for 3 consecutive days using the Lethbridge Research Centre Ruminal $\mathrm{pH}$ Measurement System (Dascor, Escondido, CA) as described by Penner et al. (2006). On d 27 through d 28 of each experimental period, $1,000 \mathrm{~mL}$ of ruminal contents were collected by manually taking $250 \mathrm{~mL}$ of ruminal contents from the cranial ventral, caudal ventral, central, and cranial dorsal rumen through the cannula just before the morning feeding at $0900 \mathrm{~h}$, and then at 4-h intervals over a 24 -h feeding cycle. Ruminal fluid samples were obtained by squeezing ruminal contents through four layers of cheesecloth. Two 5-mL aliquots of strained ruminal fluid were mixed with $1 \mathrm{~mL}$ of metaphosphoric acid (25\% wt/vol) and $1 \mathrm{~mL}$ of $1 \%$ $\mathrm{H}_{2} \mathrm{SO}_{4}$ and stored at $-20^{\circ} \mathrm{C}$ for later determination of ruminal VFA and $\mathrm{NH}_{3}-\mathrm{N}$, respectively.

\section{Sample Analyses}

At the end of the trial, frozen TMR, orts and fecal subsamples were thawed overnight at room temperature and were analyzed for DM by drying in an oven at $60^{\circ} \mathrm{C}$ for $48 \mathrm{~h}$ (AOAC, 1990). Dried TMR, orts and feces were then ground through a $1-\mathrm{mm}$ screen using a Christy-Norris mill (Christy and Norris Ltd., Chelmsford, UK) and analyzed for OM by combustion in a muffle furnace at $550^{\circ} \mathrm{C}$ for at least $8 \mathrm{~h}, \mathrm{CP}$ by the macro-Kjeldahl procedure using a Kjetec 2400 autoanalyzer to determine $\mathrm{N}$ content, ether extract and ash (AOAC, 1990). Additionally, total $\mathrm{N}$ in pooled urine samples was also determined by the macro-Kjeldahl procedure. Neutral detergent fiber and ADF were analyzed according to the procedure of Van Soest et al. (1991). Sulfite and heat-stable alpha-amylase were used for NDF analysis.

Daily urine samples that were diluted at collection were pooled per cow proportionally to daily urine output for each period and analyzed for allantoin according to Chen and Gomes (1992). Uric acid was measured according to Fossati et al. (1980) using a commercial kit (Stanbio Uric Acid Liquicolor; Stanbio Laboratories). Total purine derivative (PD; i.e., allantoin + uric acid) excretion per day was used to estimate microbial $\mathrm{N}$ yield as described by Chen and Gomes (1992) with the exception that a constant endogenous PD fraction of $56.86 \mathrm{mmol} / \mathrm{d}$ was used in the calculation (GonzalezRonquillo et al., 2003). Plasma urea-N and urinary urea-N were determined by the diacetyl monoxime method of Marsh et al. (1957) using a commercial kit (Stanbio Urea Nitrogen Kit, Stanbio Laboratories).
To determine the proportions of $\left[{ }^{15} \mathrm{~N}^{15} \mathrm{~N}\right]-,\left[{ }^{14} \mathrm{~N}^{15} \mathrm{~N}\right]-$, and $\left[{ }^{14} \mathrm{~N}^{14} \mathrm{~N}\right]$-urea in urinary urea, an aliquot of urine that contained $1.5 \mathrm{mg}$ of urea- $\mathrm{N}$ was passed through prepacked cation exchange resin columns (AG-50W- $\times 8$ Resin, 100-200 mesh, $\mathrm{H}^{+}$form; Biorad, Richmond, CA) as described by Archibeque et al. (2001). After the urine had been applied to the column, $7 \mathrm{~mL}$ of $\mathrm{N}$-free water was then applied to the columns, with the eluate discarded. Urea was then eluted by applying $20 \mathrm{~mL}$ of $\mathrm{N}$ free water to the columns, which was collected into test tubes. The eluate was air-dried at $60^{\circ} \mathrm{C}$, and urea was quantitatively transferred into $17-\times 60$-mm borosilicate glass tubes using three, $1-\mathrm{mL}$ rinses of $\mathrm{N}$-free water. The urea samples were then freeze-dried and the proportions of $\left[{ }^{15} \mathrm{~N}^{15} \mathrm{~N}\right]-$-, $\left[{ }^{14} \mathrm{~N}^{15} \mathrm{~N}\right]-$, and $\left[{ }^{14} \mathrm{~N}^{14} \mathrm{~N}\right]$-urea in urinary urea were analyzed by isotope ratio-mass spectrometry (Lobley et al., 2000) at the N-15 Analysis Laboratory, University of Illinois at Urbana-Champaign. Under the conditions of this assay, $\left[{ }^{14} \mathrm{~N}^{14} \mathrm{~N}\right]-,\left[{ }^{14} \mathrm{~N}^{15} \mathrm{~N}\right]-$, and $\left[{ }^{15} \mathrm{~N}^{15} \mathrm{~N}\right]$-urea molecules should yield ions with mass/charge $(\mathrm{m} / \mathrm{z})$ values of 28,29 , and 30 , respectively. To account for nonmonomolecular reactions, standards that were prepared from $\left[{ }^{15} \mathrm{~N}^{15} \mathrm{~N}\right]$-urea $(99.8$ atom $\%$ ${ }^{15} \mathrm{~N}$ ) and $\left[{ }^{14} \mathrm{~N}^{14} \mathrm{~N}\right]$-urea (natural abundance urea; 0.364 atoms $\%{ }^{15} \mathrm{~N}$ ) were also analyzed, and the necessary corrections for $\left[{ }^{14} \mathrm{~N}^{15} \mathrm{~N}\right]$-urea that is produced by nonmonomolecular reactions were then made (Lobley et al., 2000). Fecal grab samples that were collected daily during the total collection period were thawed overnight at room temperature and were analyzed for $\mathrm{DM}$ by drying in an oven at $60^{\circ} \mathrm{C}$ for $48 \mathrm{~h}$ (AOAC, 1990). Dried feces were then ground through a $1-\mathrm{mm}$ screen using a Christy-Norris mill (Christy and Norris Ltd., Chelmsford, UK) and subsequently ground to a fine powder using a rotating ball mill. Finely ground fecal samples were then analyzed for total ${ }^{15} \mathrm{~N}$ enrichment by combustion to $\mathrm{N}_{2}$ gas in an elemental analyzer and continuous flow isotope ratio-mass spectrometry as described by Lobley et al. (2000).

Ruminal fluid samples were thawed at room temperature, centrifuged at $18,000 \times g$ for $15 \mathrm{~min}$ and filtered through a $0.45-\mu \mathrm{m}$ membrane. A $0.9-\mathrm{mL}$ portion of the filtered supernatant was mixed with $0.1 \mathrm{~mL}$ of $10 \mathrm{mg} /$ $\mathrm{mL}$ of crotonic acid as an internal standard. Ruminal VFA were separated and quantified by gas chromatography (Agilent 6890, Mississauga, Ontario, Canada) as described by Erwin et al. (1961). Similarly, ruminal fluid samples for ruminal $\mathrm{NH}_{3}-\mathrm{N}$ determination were thawed, centrifuged for $10 \mathrm{~min}$ at $18,000 \times g$ to obtain a clear supernatant, and then analyzed using a phenolhypochlorite assay (Broderick and Kang, 1980).

\section{Calculation of Urea-N Kinetics}

Urea-N kinetics was calculated according to the model of Lobley et al. (2000), using urinary ${ }^{15} \mathrm{~N}$ enrich- 
ment of $\left[{ }^{15} \mathrm{~N}^{15} \mathrm{~N}\right],\left[{ }^{14} \mathrm{~N}^{15} \mathrm{~N}\right]$ and $\left[{ }^{14} \mathrm{~N}^{14} \mathrm{~N}\right]$ urea and total ${ }^{15} \mathrm{~N}$ excretion in feces. In this model, a portion of urea$\mathrm{N}$ synthesized in the liver (urea-N entry rate, UER) is lost via the urine (urinary urea-N elimination, UUE), and the remainder enters the GIT (GIT entry rate, GER). The urea-N entering the GIT (i.e., GER) undergoes bacterial degradation liberating $\mathrm{NH}_{3}$. A portion of this $\mathrm{NH}_{3}$ is excreted in feces (urea-N in feces, UFE), some is reabsorbed into portal blood and it reenters the ornithine cycle in the liver (ROC), and the remainder is used for anabolic purposes; that is, synthesis of microbial protein (urea-N utilized for anabolism, UUA) (Lobley et al., 2000).

\section{Statistical Analysis}

All data were analyzed using PROC MIXED (SAS Institute, 2004). The statistical model that was used for DM intake, $\mathrm{N}$ balance and nutrient digestibilities, urea-N kinetics, and PD excretion included the following terms: method of barley processing and source of supplemental fat, which were considered fixed, the interaction between method of barley processing and source of supplemental fat, the random effects of period and cow, and the residual error. Data on milk yield, milk composition, ruminal $\mathrm{pH}$, and ruminal concentrations of VFA and $\mathrm{NH}_{3}-\mathrm{N}$ were analyzed accounting for repeated measures as recommended by Wang and Goonewardene (2004) for the analysis of animal experiments. Data for these repeated measurements were analyzed by including in the model a REPEATED model statement, as well as terms for time (hour or day), and interactions (method of barley processing $\times$ time, source of supplemental fat $\times$ time, and time $\times$ method of barley processing $\times$ source of supplemental fat) in the model described previously. When processing $\times$ time or oilseed $\times$ time interactions were significant, the slice option for the LSMEANS statement in PROC MIXED was used to determine which time period means were different. Significance for all models was declared at $P \leq 0.05$, and trends are discussed for $0.05<P \leq 0.10$. When there was a significant interaction between method of barley processing and source of supplemental fat, least square means were separated by Tukey's HSD test (SAS Institute, 2004).

\section{RESULTS AND DISCUSSION}

\section{Diet Characteristics}

The ingredient composition and chemical analysis of experimental TMR is presented in Table 1 . The experimental diets were formulated to meet requirements for dairy cows that were $650 \mathrm{~kg}$ of BW, producing $32 \mathrm{~kg} / \mathrm{d}$ of milk with $3.6 \%$ fat (NRC, 2001). Diets were formu- lated to be isonitrogenous and isolipidic, and chemical analysis indicates that this was achieved (Table 1). Mean total dietary fat was $5.3 \%$, and this falls within the desired range of $<6 \%$ total dietary fat. Dietary fat levels exceeding 6 to $7 \%$ reduce fiber digestion and, consequently, lower DM intake in dairy cows (NRC, 2001); hence, it was desired to maintain total dietary fat below 6\% of DM. Whole canola seed and whole flaxseed were chosen to be used as supplemental fat sources in this experiment for 2 major reasons. First, they are both readily available and are commonly used in dairy cow diets in western Canada and the northern United States. Second, canola seed and flaxseed differ in their unsaturated fatty acid contents. The fatty acid (FA) composition (g per $100 \mathrm{~g}$ of $\mathrm{FA}$ ) of canola seed was $\mathrm{C}_{16: 0}$, 5.44; $\mathrm{C}_{16: 1}, 0.23 ; \mathrm{C}_{18: 0}, 1.77 ; \mathrm{C}_{18: 1}, 57.1 ; \mathrm{C}_{18: 2}, 22.9$; and $\mathrm{C}_{18: 3}, 11.7$. The FA composition ( $\mathrm{g} / 100 \mathrm{~g}$ of $\left.\mathrm{FA}\right)$ of flaxseed was: $\mathrm{C}_{12: 0}, 0.04 ; \mathrm{C}_{14: 0}, 0.16 ; \mathrm{C}_{14: 1}, 0.03 ; \mathrm{C}_{16: 0}, 6.28$; $\mathrm{C}_{16: 1}, 0.15 ; \mathrm{C}_{18: 0}, 3.32 ; \mathrm{C}_{18: 1}, 16.7 ; \mathrm{C}_{18: 2}, 15.2$; and $\mathrm{C}_{18: 3}$, 55.3. Therefore, canola seed is high in oleic $\left(\mathrm{C}_{18: 1}\right)$ and linoleic acids $\left(\mathrm{C}_{18: 2}\right)$, whereas flaxseed is high in linolenic acid $\left(\mathrm{C}_{18: 3}\right)$. In addition, these oilseeds differed in their iodine values, (calculated from individual FA composition; AOCS, 1989), with mean values of 112 to 115 and 190 for canola seed and flaxseed, respectively. Because of these differences in the degree of unsaturation of these oilseeds, we expected that their impacts on ruminal microbes and, consequently, on ruminal fermentation patterns would be different.

Dietary ruminally fermentable carbohydrate was altered via barley grain processing (i.e., dry-rolling vs. pelleting). Pelleting was expected to decrease particle size, thus shifting the site of carbohydrate digestion from postruminal sites to the rumen, which, consequently, would increase ruminal energy availability. Previous in situ studies in our laboratory clearly indicated a higher soluble starch fraction, a higher degradation rate of the degradable starch fraction and a higher effective starch degradability of pelleted barley when compared with dry-rolled barley (Kiran and Mutsvangwa, 2007). In the present study, a more acidic ruminal environment in cows fed pelleted barley compared with those fed dry-rolled barley is consistent with a shift in site of starch digestion. Also, barley grain was used because it is the principal cereal grain that is included in dairy cow diets in western Canada, and it is commonly fed dry-rolled or pelleted.

\section{Patterns of Ruminal Fermentation}

Ruminal $\mathrm{pH}$ was 0.22 to $0.40 \mathrm{pH}$ units greater $(P=$ $0.05)$ in cows fed dry-rolled barley compared with those fed pelleted barley (Table 2). This was expected because more extensive processing of barley would result in a 
Table 2. Ruminal fermentation characteristics in dairy cows fed TMR with dry-rolled or pelleted barley and containing canola or flaxseed as supplemental fat sources

\begin{tabular}{|c|c|c|c|c|c|c|c|c|}
\hline \multirow[b]{3}{*}{ Item } & \multicolumn{2}{|c|}{ Canola } & \multicolumn{2}{|c|}{ Flax } & \multirow[b]{3}{*}{ SEM } & \multirow{2}{*}{\multicolumn{3}{|c|}{$P$-value ${ }^{1}$}} \\
\hline & \multirow{2}{*}{$\begin{array}{c}\text { Dry-rolled } \\
\text { barley }\end{array}$} & \multirow{2}{*}{$\begin{array}{c}\text { Pelleted } \\
\text { barley }\end{array}$} & \multirow{2}{*}{$\begin{array}{c}\text { Dry-rolled } \\
\text { barley }\end{array}$} & \multirow{2}{*}{$\begin{array}{c}\text { Pelleted } \\
\text { barley }\end{array}$} & & & & \\
\hline & & & & & & BP & OS & $\mathrm{BP} \times \mathrm{OS}$ \\
\hline Ruminal pH & 6.13 & 5.73 & 5.99 & 5.77 & 0.11 & 0.05 & 0.66 & 0.48 \\
\hline Ammonia, mg/dL & 19.9 & 13.9 & 17.2 & 15.5 & 1.3 & 0.02 & 0.65 & 0.27 \\
\hline Volatile fatty acids, $\mathrm{m} M$ & & & & & & & & \\
\hline Acetate & 90.0 & 74.0 & 85.8 & 73.6 & 1.4 & $<0.001$ & 0.13 & 0.20 \\
\hline Propionate & 31.1 & 35.7 & 28.3 & 37.3 & 2.1 & 0.007 & 0.50 & 0.31 \\
\hline Isobutyrate & 0.38 & 0.28 & 0.34 & 0.26 & 0.02 & $<0.001$ & 0.08 & 0.37 \\
\hline Butyrate & $19.0^{\mathrm{a}}$ & $15.4^{\mathrm{b}}$ & $17.7^{\mathrm{b}}$ & $16.1^{\mathrm{b}}$ & 0.7 & $<0.001$ & 0.91 & 0.76 \\
\hline Isovalerate & 0.96 & 0.66 & 1.05 & 0.63 & 0.07 & $<0.001$ & 0.41 & 0.002 \\
\hline Valerate & 1.93 & 2.58 & 1.71 & 2.96 & 0.31 & 0.005 & 0.72 & 0.21 \\
\hline Total VFA & 143.3 & 128.5 & 134.9 & 130.6 & 3.4 & 0.007 & 0.35 & 0.13 \\
\hline Acetate:propionate ratio & $3.0^{\mathrm{a}}$ & $2.4^{\mathrm{b}}$ & $3.2^{\mathrm{a}}$ & $2.2^{\mathrm{c}}$ & 0.13 & $<0.001$ & 0.05 & 0.006 \\
\hline
\end{tabular}

${ }^{\mathrm{a}-\mathrm{c}}$ Means within rows with different superscripts differ $(P<0.05)$.

${ }^{1} \mathrm{BP}=$ method of barley processing (dry-rolled vs. pelleted); OS = source of supplemental fat (canola vs. flax); $\mathrm{BP} \times \mathrm{OS}=$ interaction.

more rapid and extensive ruminal carbohydrate fermentation (Huntington, 1997), thus increasing the risk of ruminal acidosis. Similarly, Yang et al. (2000) reported a lower ruminal $\mathrm{pH}$ in cows fed medium- or flatrolled barley compared with those fed coarsely-rolled barley. Individual and total concentrations of VFA were greater $(P<0.05)$ in cows fed dry-rolled barley compared with those fed pelleted barley; consequently, the acetate:propionate ratio was higher $(P<0.001)$ in cows fed dry-rolled barley compared with those fed pelleted barley (Table 2). As the rate of ruminal starch degradation is expected to differ with method of grain processing, it is reasonable to expect differences in ruminal VFA patterns, particularly acetate and propionate, when barley grain is fed dry-rolled or pelleted. There were no time $\times$ method of barley processing interactions for the major ruminal VFA; however, there was a time $\times$ method of barley processing interaction for valerate $(P=0.01)$ because ruminal concentrations of valerate were similar at feeding, but were higher at all other sampling times in cows fed dry-rolled barley compared with those fed pelleted barley (data not shown). In addition, there was a time $\times$ method of barley processing interaction for isovalerate $(P<0.001)$ because ruminal concentrations of isovalerate were higher at all sampling times during the first $20 \mathrm{~h}$ after the first feeding in cows fed dry-rolled barley compared with those fed pelleted barley, but were similar thereafter (data not shown). There were no effects of source of supplemental fat on ruminal VFA (Table 2); however, there was a time $\times$ source of supplemental fat interaction $(P<0.01)$ for butyrate because ruminal butyrate concentrations were higher at $8 \mathrm{~h}$ after the first feeding, but tended $(P<0.1)$ to be lower at 16 and $20 \mathrm{~h}$ after the first feeding, in cows fed whole canola seed compared with those fed whole flaxseed (data not shown). In addition, there was a time $\times$ source of supplemental fat interaction $(P=$ 0.04 ) for isobutyrate as ruminal isobutyrate concentrations tended $(P<0.10)$ to be higher at 12 and $20 \mathrm{~h}$ after the first feeding, but were higher $(P=0.01)$ at $16 \mathrm{~h}$ after the first feeding in cows fed whole canola seed compared with those fed whole flaxseed (data not shown).

Across dietary treatments, ruminal $\mathrm{NH}_{3}-\mathrm{N}$ concentrations ranged from 13.9 to $19.9 \mathrm{mg} / \mathrm{dL}$ and mean ruminal $\mathrm{NH}_{3}-\mathrm{N}$ concentrations at all sampling times postfeeding were $>5 \mathrm{mg} / \mathrm{dL}$ (data not shown), which has been suggested to be optimum for maximum microbial protein synthesis (Satter and Slyter, 1974). Ruminal $\mathrm{NH}_{3}-\mathrm{N}$ concentration was greater $(P=0.02)$ in cows fed dry-rolled barley compared with those fed pelleted barley (Table 2). The lower ruminal $\mathrm{NH}_{3}-\mathrm{N}$ concentration in cows fed pelleted barley likely reflects reduced microbial proteolytic activity as a result of a more acidic ruminal environment (Van Soest, 1994). Conversely, a lower ruminal $\mathrm{NH}_{3}-\mathrm{N}$ concentration may also be as a result of a higher level of utilization of $\mathrm{NH}_{3}-\mathrm{N}$ as a result of more readily available carbohydrate in pelleted barley diets (Hristov et al., 2001). In agreement with our observations, Yang et al. (2000, 2001) also reported a lower ruminal $\mathrm{NH}_{3}-\mathrm{N}$ concentration in cows fed more extensively processed barley compared with those fed coarsely rolled barley. There was a time $x$ method of barley processing interaction for ruminal $\mathrm{NH}_{3}-\mathrm{N}$ concentration $(P<0.001)$ because ruminal $\mathrm{NH}_{3}-$ $\mathrm{N}$ concentrations were higher in cows fed dry-rolled barley compared with those fed pelleted barley for the first $8 \mathrm{~h}$ after the first feeding, but ruminal $\mathrm{NH}_{3}-\mathrm{N}$ concentrations were similar thereafter (data not shown). 
Table 3. Dry matter intakes and total tract nutrient digestibilities in dairy cows fed TMR with dry-rolled or pelleted barley and containing canola or flaxseed as supplemental fat sources

\begin{tabular}{|c|c|c|c|c|c|c|c|c|}
\hline \multirow[b]{3}{*}{ Item } & \multicolumn{2}{|c|}{ Canola } & \multicolumn{2}{|c|}{ Flax } & \multirow[b]{3}{*}{ SEM } & \multirow{2}{*}{\multicolumn{3}{|c|}{$P$-value ${ }^{1}$}} \\
\hline & \multirow{2}{*}{$\begin{array}{c}\text { Dry-rolled } \\
\text { barley }\end{array}$} & \multirow{2}{*}{$\begin{array}{c}\text { Pelleted } \\
\text { barley }\end{array}$} & \multirow{2}{*}{$\begin{array}{c}\text { Dry-rolled } \\
\text { barley }\end{array}$} & \multirow{2}{*}{$\begin{array}{c}\text { Pelleted } \\
\text { barley }\end{array}$} & & & & \\
\hline & & & & & & $\mathrm{BP}$ & OS & $\mathrm{BP} \times \mathrm{OS}$ \\
\hline DMI, kg/d & 22.3 & 21.1 & 23.8 & 20.5 & 1.0 & 0.04 & 0.65 & 0.34 \\
\hline Nutrient digestibility, \% & & & & & & & & \\
\hline $\mathrm{DM}$ & 69.2 & 67.5 & 68.3 & 68.4 & 2.7 & 0.78 & 0.99 & 0.75 \\
\hline Starch & 89.8 & 98.5 & 89.8 & 99.0 & 1.2 & $<0.0001$ & 0.85 & 0.85 \\
\hline Crude fat & 88.1 & 88.6 & 86.7 & 87.1 & 1.3 & 0.8 & 0.31 & 0.95 \\
\hline $\mathrm{ADF}$ & 45.7 & 37.6 & 43.3 & 43.7 & 4.9 & 0.44 & 0.71 & 0.40 \\
\hline $\mathrm{NDF}$ & 47.3 & 42.7 & 45.8 & 47.1 & 4.2 & 0.71 & 0.74 & 0.50 \\
\hline $\mathrm{OM}$ & 70.6 & 69.2 & 69.7 & 70.3 & 2.7 & 0.88 & 0.97 & 0.73 \\
\hline
\end{tabular}

${ }^{1} \mathrm{BP}=$ method of barley processing (dry-rolled vs. pelleted); OS = source of supplemental fat (canola vs. flax); $\mathrm{BP} \times \mathrm{OS}=$ interaction.

\section{DMI and Total Tract Digestibilities}

Dry matter intake was affected $(P=0.04)$ by method of barley grain processing, with cows fed dry-rolled barley consuming 1.2 to $3.3 \mathrm{~kg} / \mathrm{d}$ more DM compared with those fed pelleted barley (Table 3). This depression in DMI with more extensive barley processing is likely mediated via increased acidity in the rumens of cows fed pelleted barley. The lower DMI in cows consuming pelleted barley compared with those fed dry-rolled barley diets is in agreement with results reported by Yang et al. (2000), who observed a quadratic response in DMI of dairy cows fed barley grain processed to varying degrees, ranging from coarsely rolled to flat-rolled. In feedlot cattle, Hironaka et al. (1992) observed lower DMI and a higher incidence of digestive disturbances when thinly-rolled or medium-rolled barley diets were fed compared with coarsely rolled or whole barley diets. In contrast, Yang et al. (2001) reported higher DMI in cows fed flatly rolled barley compared with those fed coarsely rolled barley; however, the decrease in ruminal $\mathrm{pH}(-0.13 \mathrm{pH}$ units) observed with more extensive barley grain processing in that study was not as severe as that observed in the present study $(-0.31 \mathrm{pH}$ units), and this could explain the discrepancy in results. Source of dietary supplemental fat did not affect DMI (Table 3). Mean DMI was $22 \mathrm{~kg} / \mathrm{d}$, or approximately $3.4 \%$ of mean $\mathrm{BW}$, and this falls within the expected range for dairy cows producing $32 \mathrm{~kg} / \mathrm{d}$ of milk (NRC, 2001). Therefore, it is unlikely that feeding supplemental fat decreased DMI. These results are in agreement with those of Ward et al. (2002) in which DMI was similar in cows fed barley-based diets that contained canola or flax as a supplemental fat source.

Total tract digestibilities of $\mathrm{DM}$, crude fat, $\mathrm{ADF}$, $\mathrm{NDF}$, and OM were unaffected $(P>0.05)$ by method of barley processing or source of oilseed (Table 3); however, total tract starch digestibility was higher $(P<$ 0.0001) in cows fed pelleted barley compared with those fed dry-rolled barley (Table 3). In contrast, Yang et al. (2001) reported higher DM and OM digestibilities in cows fed flatly rolled barley compared with those fed coarsely rolled barley; however, in agreement with our observations, $\mathrm{ADF}$ and NDF digestibilities were not altered. Feeding dry-rolled barley may have reduced the rate of starch fermentability in the rumen, whereas feeding pelleted barley led to a more rapid and complete ruminal starch degradation and, hence, higher starch digestibilities. The lack of effect of barley grain processing on $\mathrm{ADF}$ and NDF digestion is somewhat surprising because pelleting barley increased ruminal acidity when compared with dry-rolling. This is possibly due to a higher hindgut fermentation of ADF and NDF in cows fed dry-rolled barley compared with those fed pelleted barley, thus compensating for any depression in ruminal fiber digestion that might have occurred. Across dietary treatments, our estimates of total tract digestibilities of $\mathrm{ADF}$ and $\mathrm{NDF}$ are similar to previous observations in cows fed similar diets (T. Mutsvangwa, unpublished data); however, it is noteworthy that our estimates of ADF and NDF digestibilities are numerically lower than has been previously observed in cows fed diets with similar ingredient compositions (Yang et al., 2000). Lower ADF and NDF digestibilities observed in the present study might be attributed to depressed ruminal $\mathrm{pH}$. In a previous study (Yang et al., 2000) reporting higher $\mathrm{ADF}$ and NDF digestibilities, mean ruminal $\mathrm{pH}$ was 0.17 to $0.43 \mathrm{pH}$ units higher when compared with mean ruminal $\mathrm{pH}$ values observed in the present study. Across all diets, mean ruminal $\mathrm{pH}$ ranged from 5.73 to 6.11 (mean of 5.91), which is lower than the ruminal $\mathrm{pH}$ of 6.2 which has been suggested as the minimum ruminal $\mathrm{pH}$ for optimum fiber digestion (Van Soest, 1994). Previously, in vitro studies indicated that populations of the principal fiber-digesting bacteria such as Fibrobacter spp. and Ruminococcus albus decline rapidly when $\mathrm{pH}$ falls below 6.0 (Russell 
Table 4. Milk yield and milk composition in dairy cows fed TMR with dry-rolled or pelleted barley and containing canola or flaxseed as supplemental fat sources

\begin{tabular}{|c|c|c|c|c|c|c|c|c|}
\hline \multirow[b]{3}{*}{ Item } & \multicolumn{2}{|c|}{ Canola } & \multicolumn{2}{|c|}{ Flax } & \multirow[b]{3}{*}{ SEM } & \multirow{2}{*}{\multicolumn{3}{|c|}{$P$-value ${ }^{1}$}} \\
\hline & \multirow{2}{*}{$\begin{array}{c}\text { Dry-rolled } \\
\text { barley }\end{array}$} & \multirow{2}{*}{$\begin{array}{c}\text { Pelleted } \\
\text { barley }\end{array}$} & \multirow{2}{*}{$\begin{array}{c}\text { Dry-rolled } \\
\text { barley }\end{array}$} & \multirow{2}{*}{$\begin{array}{c}\text { Pelleted } \\
\text { barley }\end{array}$} & & & & \\
\hline & & & & & & $\mathrm{BP}$ & OS & $\mathrm{BP} \times \mathrm{OS}$ \\
\hline Actual milk yield, $\mathrm{kg} / \mathrm{d}$ & 32.3 & 32.4 & 33.1 & 28.1 & 3.42 & 0.41 & 0.56 & 0.39 \\
\hline ECM yield,$^{2} \mathrm{~kg} / \mathrm{d}$ & 31.4 & 30.1 & 29.8 & 27.6 & 2.02 & 0.29 & 0.23 & 0.74 \\
\hline Fat, \% & 3.40 & 2.63 & 3.54 & 2.71 & 0.32 & $<0.0001$ & 0.37 & 0.77 \\
\hline Fat yield, $\mathrm{kg} / \mathrm{d}$ & 1.10 & 0.80 & 1.15 & 0.72 & 0.04 & $<0.0001$ & 0.78 & 0.09 \\
\hline Protein, \% & 2.98 & 3.18 & 3.16 & 3.30 & 0.15 & 0.005 & 0.01 & 0.62 \\
\hline Protein yield, kg/d & $0.96^{\mathrm{ab}}$ & $1.00^{\mathrm{a}}$ & $1.03^{\mathrm{a}}$ & $0.89^{b}$ & 0.05 & 0.13 & 0.45 & 0.006 \\
\hline
\end{tabular}

${ }^{\mathrm{a}, \mathrm{b}}$ Means within rows with different superscripts differ $(P<0.05)$.

${ }^{1} \mathrm{BP}=$ method of barley processing (dry-rolled vs. pelleted); OS = source of supplemental fat (canola vs. flax); $\mathrm{BP} \times \mathrm{OS}=$ interaction.

${ }^{2} \mathrm{ECM}$ yield $=$ milk yield corrected to $3.5 \%$ fat and $3.2 \%$ protein using the following equation: $\mathrm{ECM}, \mathrm{kg}=$ $(12.82 \times \mathrm{kg}$ of fat $)+(7.13 \times \mathrm{kg}$ of protein $)+(0.323 \times \mathrm{kg}$ of milk; Tyrrell and Reid, 1965)

and Wilson, 1996). In addition, total dietary fat in the present study was high (>5\%; DM basis) and composed mainly of unsaturated fatty acids. In general, supplemental fat sources that are high in unsaturated fatty acids can have inhibitory effects on ruminal fiber digestion (Schauff et al., 1992; Pantoja et al., 1994), thus partially explaining the lower fiber digestibilities observed in the present study when compared with another study (Yang et al., 2000) in which total dietary fat contents were lower.

\section{Milk Yield and Milk Composition}

Actual and ECM were not affected by method of barley grain processing or source of supplemental fat (Table 4). These findings are similar to those by Ward et al. (2002) in which inclusion of flax or canola as supplemental fat source in barley-based diets to attain a dietary fat content of 6\% (DM basis) did not affect milk yield. Milk fat content $(P<0.0001)$ and milk fat yield $(P<0.0001)$ were higher in cows fed dry-rolled barley than in cows fed pelleted barley (Table 4). Milk fat contents were 3.47 and $2.67 \%$, and milk fat yields were 1.13 and $0.76 \mathrm{~kg} / \mathrm{d}$ for cows fed dry-rolled barley and pelleted barley, respectively. Thus, milk fat yield tended $(P=0.09)$ to be lower due to the milk fat depression observed with pelleted barley, and these changes mirrored the numerical changes in milk yield. The milk fat depression observed in cows fed pelleted barley is likely attributed to ruminal fermentation changes, resulting in depressed ruminal $\mathrm{pH}$ and associated changes in ruminal biohydrogenation pathways. Previously, in vitro studies indicated that depressed $\mathrm{pH}$ altered biohydrogenation pathways of unsaturated fatty acids, such that there was an accumulation of $\mathrm{C}_{18: 1}$ trans-10 and conjugated linoleic acid isomers (Van Nevel and Demeyer, 1996; Qui et al., 2004). These un- saturated fatty acids are potent inhibitors of de novo synthesis of short-chain fatty acids in the mammary gland (Bauman and Griinari, 2001). In the present study, postruminal flow of conjugated linoleic acid isomers and $\mathrm{C}_{18: 1}$ trans-10, or milk fatty acid composition, were not measured. However, the milk fat depression in cows fed pelleted barley suggests that postruminal flow of these biohydrogenation intermediates may have been higher than in cows fed dry-rolled barley. Additionally, a lower ruminal acetate:propionate ratio in cows fed pelleted barley compared with those fed dryrolled barley may be a possible cause for the observed milk fat depression. Others have reported milk fat depression when ruminal fermentation was altered sufficiently to decrease acetate: propionate ratios (Griinari et al., 1998; Onetti et al., 2002). Milk protein content was higher $(P=0.005)$ in cows fed dry-rolled barley compared with those fed pelleted barley (Table 4). Additionally, feeding whole flaxseed as supplemental fat resulted in higher $(P=0.01)$ milk protein content compared with feeding whole canola (Table 4). Previous studies in which dietary barley grain was processed more extensively (Yang et al., 2001), or whole canola and flaxseed were added as supplemental fat sources (Ward et al., 2002) have also reported changes in milk protein content and milk protein yield.

\section{Nitrogen Balance}

Cows fed dry-rolled barley consumed 1.2 to $3.3 \mathrm{~kg} / \mathrm{d}$ more DM compared with those fed pelleted barley, which resulted in cows fed dry-rolled barley consuming 40 to $113 \mathrm{~g} / \mathrm{d}$ more $\mathrm{N}$ compared with those fed pelleted barley $(P=0.02$; Table 5$)$. However, fecal $\mathrm{N}$ excretion was higher $(P=0.002)$ in cows fed dry-rolled barley compared with those fed pelleted barley (Table 5). As a result, cows fed dry-rolled barley had a lower $(P=$ 
Table 5. $\mathrm{N}$ balance, $\mathrm{N}$ digestibility, and plasma urea-N in dairy cows fed TMR with dry-rolled or pelleted barley and containing canola or flaxseed as supplemental fat sources

\begin{tabular}{|c|c|c|c|c|c|c|c|c|}
\hline \multirow[b]{3}{*}{ Item } & \multicolumn{2}{|c|}{ Canola } & \multicolumn{2}{|c|}{ Flax } & \multirow[b]{3}{*}{ SEM } & \multirow{2}{*}{\multicolumn{3}{|c|}{$P$-value ${ }^{1}$}} \\
\hline & Drv-rolled & Pelleted & Dry-rolled & & & & & \\
\hline & barley & barley & barley & barley & & $\mathrm{BP}$ & OS & $\mathrm{BP} \times \mathrm{OS}$ \\
\hline $\mathrm{N}$ intake, g/d & 622.9 & 583.1 & 653.2 & 539.5 & 29.1 & 0.01 & 0.82 & 0.23 \\
\hline Fecal N, g/d & 159.8 & 132.4 & 196.9 & 116.2 & 12.8 & 0.002 & 0.44 & 0.06 \\
\hline Urine $\mathrm{N}, \mathrm{g} / \mathrm{d}$ & 291.1 & 261.8 & 266.5 & 242.7 & 54.8 & 0.64 & 0.70 & 0.96 \\
\hline Milk N, g/d & 150.5 & 158.5 & 162.0 & 137.0 & 11.8 & 0.49 & 0.68 & 0.19 \\
\hline $\mathrm{N}$ digestibility, \% & 74.1 & 77.1 & 70.5 & 78.3 & 2.5 & 0.05 & 0.65 & 0.35 \\
\hline $\mathrm{N}$ retention, $\mathrm{g} / \mathrm{d}$ & 21.5 & 30.4 & 27.8 & 43.7 & 47.9 & 0.80 & 0.84 & 0.94 \\
\hline Plasma urea-N, mg/dL & 17.1 & 14.4 & 15.3 & 15.1 & 1.1 & 0.20 & 0.62 & 0.26 \\
\hline
\end{tabular}

${ }^{1} \mathrm{BP}=$ method of barley processing (dry-rolled vs. pelleted); OS = source of supplemental fat (canola vs. flax); $\mathrm{BP} \times \mathrm{OS}=$ interaction.

0.05) apparent $\mathrm{N}$ digestibility compared with those fed pelleted barley (Table 5). Lower apparent $\mathrm{N}$ digestibilities in cows fed dry-rolled barley compared with those fed pelleted barley suggest that a larger fraction of dietary starch was able to bypass the rumen and was digested in the lower GIT. Shifting starch digestion to the lower GIT promotes hindgut fermentation and leads to more bacterial protein synthesis in the hindgut (Ørskov et al., 1970); however, there are no mechanisms for digestion and absorption of the resultant bacterial protein, which is subsequently voided in the feces. Nitrogen use (i.e., $\mathrm{N}$ secreted in milk, $\mathrm{N}$ retained by the animal, or excreted in urine $\mathrm{N})$ were not affected $(P>$ 0.05 ) by dietary treatment (Table 5). In the present study, we observed a rather large variability in urinary and fecal $\mathrm{N}$ excretion, so these data on $\mathrm{N}$ balance should be interpreted somewhat cautiously. Spanghero and Kowalski (1997) conducted a meta-analysis of 35 trials that were conducted with dairy cows and found that the mean and median $\mathrm{N}$ balance were 39 and $24 \mathrm{~g} /$ $\mathrm{d}$, respectively. In the present study, mean $\mathrm{N}$ balance ranged from 21.5 to $43.7 \mathrm{~g} / \mathrm{d}$, which encompasses the mean N balance reported by Spanghero and Kowalski (1997). Typically, $\mathrm{N}$ balance is calculated as $\mathrm{N}$ intake - (milk $\mathrm{N}+$ fecal $\mathrm{N}+$ urine $\mathrm{N})$; therefore, any errors that occur in the measurement of any of the 4 variables that are included in this calculation will be reflected in the $\mathrm{N}$ balance data. In addition, $\mathrm{N}$ balance data from studies with dairy cows have often been shown to be inherently flawed because the methodologies used often result in unaccountable $\mathrm{N}$ losses (Spanghero and Kowalski, 1997). In the present study, it is also possible that urinary and fecal $\mathrm{N}$ were underestimated due to possible gaseous $\mathrm{N}$ losses particularly during sample collection and processing (e.g., oven drying of fecal samples might have resulted in the loss of volatile N-containing compounds); however, the magnitude of these losses, if any, is unknown. Plasma urea-N concentration was not affected $(P>0.05)$ by dietary treatment (Table
5). In dairy cows, PUN largely arises from ruminal catabolism of dietary protein, with the resultant ruminal $\mathrm{NH}_{3}-\mathrm{N}$ that is not captured for microbial protein synthesis being absorbed into portal blood and converted to urea in the liver (NRC, 2001).

\section{Urea-N Kinetics and Microbial NAN Supply}

The primary objective of the present study was to determine how interactions between method of barley grain processing and source of supplemental fat alter urea-N transfer to the GIT and the utilization of this recycled urea- $\mathrm{N}$ in dairy cows as measured by the intrajugular $\left[{ }^{15} \mathrm{~N}^{15} \mathrm{~N}\right]$-urea infusion protocol. Urea synthesis (i.e., urea-N entry rate; UER) was higher $(P=0.02)$ in dairy cows fed dry-rolled barley compared with those fed pelleted barley (Table 6). Higher UER in cows fed dry-rolled barley is not surprising; an extensive evaluation of experimental data on transhepatic venous-arterial urea-N fluxes in beef and dairy cattle at variable $\mathrm{N}$ intakes and productive states indicated a strong, positive correlation $\left(\mathrm{r}^{2}=0.96\right)$ between $\mathrm{N}$ intake and hepatic output of urea-N (Huntington and Archibeque, 1999). In the present study, cows fed dry-rolled barley consumed more $\mathrm{N}$ compared with those fed pelleted barley. Recently, higher levels of UER with increasing $\mathrm{N}$ intakes have been reported in lambs (Marini et al., 2004), Holstein heifers (Marini and Van Amburgh, 2003) and beef steers (Archibeque et al., 2001). There was a tendency (interaction; $P=0.08$ ) for the difference in UER between cows fed dry-rolled barley compared with those fed pelleted barley to be greater with flax $(178.9 \mathrm{~g}$ of $\mathrm{N} / \mathrm{d})$ than canola ( $36.8 \mathrm{~g}$ of N/d), likely because the difference in $\mathrm{N}$ intake between cows fed dryrolled barley compared with those fed pelleted barley was greater with flax (113.7 $\mathrm{g}$ of N/d) than canola (39.8 $\mathrm{g}$ of $\mathrm{N} / \mathrm{d}$ ). Across dietary treatments, UER ranged from 0.72 to 1.06 of digestible $\mathrm{N}$ intake. In an elegant review of the literature, Lapierre and Lobley (2001) calculated 
Table 6. Urea-N recycling kinetics as measured using 4-d continuous jugular infusions of $\left[{ }^{15} \mathrm{~N}^{15} \mathrm{~N}\right]$-urea in dairy cows fed TMR with dry-rolled or pelleted barley and containing canola or flaxseed as supplemental fat sources

\begin{tabular}{|c|c|c|c|c|c|c|c|c|}
\hline \multirow[b]{3}{*}{ Item } & \multicolumn{2}{|c|}{ Canola } & \multicolumn{2}{|c|}{ Flax } & \multirow[b]{3}{*}{ SEM } & \multirow{2}{*}{\multicolumn{3}{|c|}{$P$-value ${ }^{1}$}} \\
\hline & Dry-rolled & Pelleted & Dry-rolled & Pelleted & & & & \\
\hline & barley & barley & barley & barley & & $\mathrm{BP}$ & OS & $\mathrm{BP} \times \mathrm{OS}$ \\
\hline \multicolumn{9}{|l|}{ Urea-N kinetics, g/d } \\
\hline Production, UER & 400.9 & 364.1 & 483.4 & 304.5 & 30.2 & 0.02 & 0.74 & 0.08 \\
\hline Entry to GIT, GER & 247.5 & 234.1 & 298.3 & 169.9 & 28.6 & 0.07 & 0.84 & 0.12 \\
\hline Return to ornithine cycle, ROC & $183.3^{\mathrm{ab}}$ & $180.8^{\mathrm{ab}}$ & $224.9^{\mathrm{a}}$ & $138.2^{\mathrm{b}}$ & 14.2 & 0.03 & 0.98 & 0.04 \\
\hline Loss to feces, UFE & 7.75 & 8.32 & 10.27 & 6.42 & 1.07 & 0.21 & 0.80 & 0.11 \\
\hline Loss to urine, UUE & 153.4 & 130.0 & 185.2 & 134.6 & 12.9 & 0.05 & 0.25 & 0.38 \\
\hline Reuse for anabolism, UUA & 56.5 & 45.0 & 63.1 & 25.2 & 18.3 & 0.27 & 0.75 & 0.53 \\
\hline \multicolumn{9}{|l|}{ Fractional urea-N transfers } \\
\hline UER to urine & 0.390 & 0.352 & 0.389 & 0.420 & 0.052 & 0.94 & 0.48 & 0.46 \\
\hline UER to GIT & 0.610 & 0.648 & 0.611 & 0.580 & 0.040 & 0.94 & 0.48 & 0.46 \\
\hline GER to ROC & 0.761 & 0.777 & 0.768 & 0.804 & 0.055 & 0.68 & 0.78 & 0.87 \\
\hline GER to feces & 0.033 & 0.035 & 0.037 & 0.035 & 0.005 & 0.88 & 0.73 & 0.69 \\
\hline GER to UUA & 0.206 & 0.188 & 0.195 & 0.161 & 0.056 & 0.68 & 0.76 & 0.89 \\
\hline
\end{tabular}

${ }^{\mathrm{a}, \mathrm{b}}$ Means within rows with different superscripts differ $(P<0.05)$.

${ }^{1} \mathrm{BP}=$ method of barley processing (dry-rolled vs. pelleted); OS = source of supplemental fat (canola vs. flax); $\mathrm{BP} \times \mathrm{OS}=$ interaction.

UER:digestible $\mathrm{N}$ intake ratios in lactating cows at various levels of production and fed a wide variety of diets, and the calculated ratios ranged from 0.43 to 1.23 (mean of 0.88 ), a range which encompasses the ratios observed in the present study. Clearly, these ratios indicate the magnitude of the transit of $\mathrm{N}$ into the urea pool and the perpetual reliance of ruminants on urea- $\mathrm{N}$ recycling to the GIT to maintain a positive $\mathrm{N}$ balance.

The quantity of urea-N synthesized that was transferred to the GIT (i.e., GER) tended to be higher ( $P=$ 0.07 ) in cows fed dry-rolled barley compared with those fed pelleted barley (Table 6). In ruminants, the ability to transfer significant amounts of urea-N to the GIT, particularly to the rumen where it can be used for microbial protein synthesis, is an important mechanism to conserve $\mathrm{N}$ (Huntington, 1989). Increasing ruminal energy supply, by increasing the amounts of readily fermentable starch fed (Kennedy and Milligan, 1980; Huntington, 1989; Rémond et al., 1996) or by increasing the proportion of dietary starch fermented in the rumen via cereal grain processing (Alio et al., 2000; Theurer et al., 2002) increases urea-N transfer to the rumen. Based on these previous studies, we expected that decreasing barley particle size through pelleting compared with dry-rolling in our study would increase ruminal starch digestion and, consequently, increase the quantitative transfer of urea-N to the rumen. However, our observations contradict these expectations. A possible explanation for this is that ruminal energy supply was not quantitatively higher in cows fed pelleted barley compared with those fed dry-rolled barley, primarily due to higher feed intake in cows fed dry-rolled barley (Table 3). The magnitude of urea-N transfer across the ruminal wall appears to be regulated by many intraruminal factors, including ruminal concentrations of VFA (particularly butyrate) and $\mathrm{NH}_{3}-\mathrm{N}$ (Rémond et al., 1996). Increasing ruminal butyrate concentration promotes higher rates of urea-N transfer to the rumen (Engelhardt et al., 1978; Rémond et al., 1993). In the present study, cows fed dry-rolled barley exhibited a higher ruminal butyrate concentration compared with those fed pelleted barley, possibly accounting for the observed differences in GER. In addition, feeding pelleted barley increased ruminal acidity, which, in turn, might have decreased bacterial urease activity in the rumen. Because bacterial urease activity facilitates the transepithelial movement of urea-N by maintaining a concentration gradient that is favorable to diffusion (Rémond et al., 1996), depressed bacterial urease activity under the acidotic conditions imposed in cows fed pelleted barley might have impaired urea-N transfer. Previous studies reporting beneficial effects of increased ruminal energy availability on urea-N transfer to the rumen did not report associated changes, if any, in ruminal $\mathrm{pH}$, so direct comparisons with the present study are not possible. When expressed as a proportion of UER, urea-N transfer to the GIT (i.e., GER:UER) was not changed $(P=0.94)$ by method of barley processing, and it ranged from 0.580 to 0.648 (Table 6). These values are similar to those observed by Alio et al. (2000) (0.50 to 0.67), and Theurer et al. (2002) (0.54 to 0.69 ) using venous-arterial techniques in beef cattle fed cereal grains processed to varying degrees.

Despite a tendency for GER to be higher in cows fed dry-rolled barley compared with those fed pelleted barley, the proportion that was used in the GIT for 
Table 7. Urinary output, urinary purine derivative (PD) excretion and microbial $\mathrm{N}$ supply in dairy cows fed TMR with dry-rolled or pelleted barley and containing canola or flaxseed as supplemental fat sources

\begin{tabular}{|c|c|c|c|c|c|c|c|c|}
\hline \multirow[b]{3}{*}{ Item } & \multicolumn{2}{|c|}{ Canola } & \multicolumn{2}{|c|}{ Flax } & \multirow[b]{3}{*}{ SEM } & \multirow{2}{*}{\multicolumn{3}{|c|}{$P$-value ${ }^{1}$}} \\
\hline & Dry-rolled & Pelleted & Dry-rolled & Pelleted & & & & \\
\hline & barley & barley & barley & barley & & $\mathrm{BP}$ & OS & $\mathrm{BP} \times \mathrm{OS}$ \\
\hline \multicolumn{9}{|l|}{ Urinary excretion } \\
\hline Total output, kg/d & 22.3 & 29.5 & 31.4 & 29.7 & 4.4 & 0.53 & 0.31 & 0.33 \\
\hline Allantoin, $\mathrm{mmol} / \mathrm{d}$ & 295.6 & 308.8 & 358.2 & 276.9 & 37.3 & 0.38 & 0.69 & 0.22 \\
\hline Uric acid, $\mathrm{mmol} / \mathrm{d}$ & 53.7 & 56.7 & 66.6 & 54.3 & 5.6 & 0.43 & 0.37 & 0.20 \\
\hline Total PD, mmol/d & 349.2 & 365.5 & 424.7 & 331.2 & 40.9 & 0.36 & 0.62 & 0.20 \\
\hline Microbial N, ${ }^{2} \mathrm{~g} / \mathrm{d}$ & 248.4 & 262.2 & 312.9 & 233.0 & 34.9 & 0.46 & 0.62 & 0.20 \\
\hline
\end{tabular}

${ }^{1} \mathrm{BP}=$ method of barley processing (dry-rolled vs. pelleted); OS = source of supplemental fat (canola vs. flax); $\mathrm{BP} \times \mathrm{OS}=$ interaction.

${ }^{2}$ Microbial N supply was calculated according to Chen and Gomes (1992), with an estimated endogenous $\mathrm{PD}$ of $56.86 \mathrm{mmol} / \mathrm{d}$ according to Gonzalez-Ronquillo et al. (2003).

anabolic purposes, both in absolute amounts (UUA) and as a proportion of GER (i.e., fractional transfer of GER to UUA), were unaffected by dietary treatment (Table 6 ). Consequently, urea-N that was recycled to the ornithine cycle (i.e., ROC) was higher $(P=0.03)$ in dairy cows fed dry-rolled barley than in cows fed pelleted barley. Urea-N that is recycled to the rumen can potentially be utilized by ruminal microorganisms to increase microbial protein synthesis and, subsequently, total metabolizable protein flow to the small intestine. Other studies investigating the effects of increased ruminal starch digestion on $\mathrm{N}$ metabolism have reported increased urea-N recycling to the rumen, with concomitant increases in microbial protein flow to the small intestine (Al-Dehneh et al., 1997) or net absorption of $\alpha$-amino N across the GIT (Alio et al., 2000). In the present study, only 0.161 to 0.206 of the GER was utilized for anabolic purposes (Table 6), and the lack of significant dietary effects on how much GER is directed toward anabolic purposes is consistent with similar microbial NAN flows as estimated using urinary PD excretion (Table 7). This lack of effect of grain processing on UUA suggests that energy supply did not limit utilization of the extra $\mathrm{N}$ provided via enhanced urea-N recycling to the GIT, probably because of the high levels of concentrate fed. It is also plausible that ruminal energy supply was quantitatively similar in cows fed dry-rolled or pelleted barley, primarily due to differences in feed intake. In addition, some ruminal bacterial species that ferment nonstructural carbohydrates have been demonstrated to have an absolute requirement for preformed peptides and amino acids (Oh et al., 1999), thus any additional ruminal $\mathrm{N}$ supply in the form of recycled urea-N could have precluded any further incorporation of $\mathrm{N}$ into microbial protein. In addition, the amount of GER that may be used for anabolic purposes will also depend on the proportion that actually enters the rumen since urea appears to enter all parts of the GIT (see Lapierre and Lobley, 2001). In the present study, a significant proportion of the GER, ranging from 0.761 to 0.804 , was reabsorbed into portal blood as $\mathrm{NH}_{3}-\mathrm{N}$ and returned to the urea cycle (GER to ROC; Table 6). Because of the high $\mathrm{N}$ intakes associated with lactating cows, a limit of $\mathrm{N}$ utilization for anabolic purposes in the GIT may already have been reached (Lobley et al., 2000), thereby limiting anabolic use of any extra N supplied via recycling. Urea-N transfer to urine (i.e., UUE) was higher $(P=0.05)$ in cows fed dry-rolled barley compared with those fed pelleted barley (Table 6). This is likely attributable to the higher rates of endogenous urea-N production (i.e., UER) that was observed in cows fed dry-rolled barley compared with those fed pelleted barley. In other studies, higher UER has been associated with increased UUE (Lobley et al., 2000; Marini and Van Amburgh, 2003; Marini et al., 2004). Urea-N transfer to feces was unaffected by method of barley grain processing (Table 6). Fractional urea-N transfers of the GER to feces ranged from 0.033 to 0.037 across diets, and this represented the smallest proportion of GER (Table 6).

Source of supplemental fat in the diet did not alter urea $\mathrm{N}$ kinetics, expressed as absolute amounts or as proportions of UER or GER (Table 6). We had hypothesized that as the degree of unsaturation of supplemental fat increased by substituting flaxseed for canola, then depressed activity of ruminal microbes, particularly ruminal protozoa, would reduce ruminal $\mathrm{NH}_{3}-\mathrm{N}$ concentrations and, as a consequence, enhance urea-N transfer from the blood into the rumen. In previous studies reporting alterations in ruminal fermentation (Jenkins, 1993), bacterial N flow to the duodenum (Pantoja et al., 1994), and the efficiency of ruminal bacterial protein synthesis (Pantoja et al., 1994; Oldick and Firkins, 2000) as the degree of unsaturation of fat supplements increased, supplemental fat sources that differed markedly in their degree of unsaturation (tallow vs. 
partially hydrogenated vs. animal-vegetable fat, with IV ranging from 10 to 110) were used. In those studies, alterations in ruminal fermentation characteristics as a result of changing supplemental fat source were usually observed, which was not the case in the present study. The absence of any effects of source of supplemental fat on urea-N kinetics may be a reflection of both oilseeds having high contents of unsaturated fatty acids and, consequently, similar impacts on patterns of ruminal fermentation.

Microbial nonammonia $\mathrm{N}$ flow to the small intestine, estimated by urinary PD excretion, was not affected by method of barley processing or source of supplemental fat (Table 7). Despite the existence of a relationship between duodenal supply of RNA and the urinary excretion of $\mathrm{PD}$, the relationship is usually obscured by an endogenous fraction coming from the turnover of nucleic acid in tissues (Chen et al., 1990) and, therefore, results must be interpreted somewhat cautiously. In the current study, a lack of dietary effect on microbial nonammonia $\mathrm{N}$ supply is consistent with the observation that, across diets, a large proportion of the GER was reabsorbed into portal blood and returned to the urea cycle (GER to ROC), and only a small proportion of the GER was utilized for anabolic purposes.

\section{CONCLUSIONS}

In summary, results from this study indicate that method of barley grain processing altered hepatic urea$\mathrm{N}$ output and urea-N recycling to the GIT. Feeding dry-rolled barley compared with feeding pelleted barley tended to increase urea-N transfer to the GIT; however, most of this $\mathrm{N}$ was returned to the ornithine cycle, suggesting that a plateau in $\mathrm{N}$ utilization may already have been reached, thus limiting the utilization of the extra $\mathrm{N}$ supplied from recycled urea-N. In consequence, even if barley grain processing altered urea-N entry into the GIT, this did not result in increased microbial protein supply at the duodenum.

\section{ACKNOWLEDGMENTS}

The authors thank Marlene Fehr and staff of the Greenbrae Dairy Research Facility, University of Saskatchewan, for animal care and excellent technical assistance. This research was supported by the Natural Sciences and Engineering Research Council of Canada (NSERC), the Saskatchewan Department of Agriculture, Food and Rural Revitalization, the Canola Council of Canada and the Saskatchewan Canola Development Commission.

\section{REFERENCES}

Al-Dehneh, A., J. T. Huber, R. Wanderley, C. B. Theurer, M. Pessarakli, and D. DeYoung. 1997. Incorporation of recycled urea-N into ruminal bacteria flowing to the small intestine of dairy cows fed a high-grain or high-forage diet. Anim. Feed Sci. Technol. 68:327-338.

Alio, A., C. B. Theurer, O. Lozano, J. T. Huber, R. S. Swingle, A. Delgado-Elorduy, P. Cuneo, D. DeYoung, and K. E. Webb Jr. 2000. Splanchnic nitrogen metabolism by growing beef steers fed diets containing sorghum grain flaked at different densities. J. Anim. Sci. 78:1355-1363.

AOAC. 1990. Official Methods of Analysis. 15th ed. Assoc. Off. Anal. Chem., Arlington, VA.

AOCS. 1989. Official Methods and Recommended Practices. 4th ed. Am. Oil Chem. Soc., Champaign, IL.

Archibeque, S. L., J. C. Burns, and G. B. Huntington. 2001. Urea flux in beef steers: Effects of forage species and fertilization. J. Anim. Sci. 79:1937-1943.

Bauman, D. E., and J. M. Griinari. 2001. Regulation and nutritional manipulation of milk fat: Low-fat syndrome. Livest. Prod. Sci. 70:15-29.

Broderick, G. A., and J. H. Kang. 1980. Automated simultaneous determination of ammonia and total amino acids in ruminal fluid and in vitro media. J. Dairy Sci. 63:64-75.

Chen, X. B., and M. J. Gomes. 1992. Estimation of microbial protein supply to sheep and cattle based on urinary excretion of purine derivatives- and overview of the technical details. International Feed Resources Unit, Rowett Research Institute, Occasional Publication 1992. http://www.macaulay.ac.uk/IFRU/pdf/chema.pdf Accessed May 2, 2007.

Chen, X. B., E. R. Ørskov, F. D. De, and B. Hovell. 1990. Excretion of purine derivatives by ruminants: Endogenous excretion, differences between cattle and sheep. Br. J. Nutr. 63:121-129.

Clark, J. H., T. H. Klusmeyer, and M. R. Cameron. 1992. Microbial protein synthesis and flows of nitrogen fractions to the duodenum of dairy cows. J. Dairy Sci. 75:2304-2323.

Egan, A. R., K. Boda, and J. Varady. 1986. Regulation of nitrogen metabolism and recycling. Pages 386-402 in Control of Digestion and Metabolism in Ruminants. L. P. Milligan, W. L. Grovum, and A. Dobson, ed. Prentice-Hall, Englewood Cliffs, NJ.

Engelhardt, W. V., S. Hinderer, and E. Wipper. 1978. Factors influencing the endogenous urea-N secretion and utilization in the gastrointestinal tract. Pages 4.1-4.12 in Ruminant Digestion and Feed Evaluation. D. F. Osbourn, D. E. Beever, and D. J. Thomson, ed. Agric. Res. Counc., London, UK.

Erwin, E. S., G. J. Marco, and E. M. Emery. 1961. Volatile fatty acids analysis of blood and rumen fluid by gas chromatography. J. Dairy Sci. 44:1768-1776.

Fossati, P., L. Prencipe, and G. Berti. 1980. Use of 3,5-dichloro-2hydroxybenzenesulfonic acid/4-aminophenazone chromogenic system in direct enzymic assay of uric acid in serum and urine. Clin. Chem. 26:227-231.

Gonzalez-Ronquillo, M., J. Balcells, J. A. Guada, and F. Vicente. 2003. Purine derivative excretion in dairy cows: Endogenous excretion and the effect of exogenous nucleic acid supply. J. Dairy Sci. $86: 1282-1291$.

Griinari, J. M., D. A. Dwyer, M. A. McGuire, D. E. Bauman, D. L. Palmquist, and K. V. Nurmela. 1998. Trans-octadecenoic acids and milk fat depression in lactating dairy cows. J. Dairy Sci. 81:1251-1261.

Hettiarachchi, M., R. M. Dixon, and J. V. Nolan. 1999. Effect of intraruminal urea infusion and changing digestible organic matter intake on nitrogen kinetics in sheep fed rice straw. J. Agric. Sci. (Camb.) 133:109-121.

Hironaka, R., K. A. Beauchemin, and T. J. Lysyk. 1992. The effect of thickness of steam-rolled barley on its utilization by beef cattle. Can. J. Anim. Sci. 72:279-286.

Hristov, A. N., M. Ivan, L. M. Rode, and T. A. McAllister. 2001. Fermentation characteristics and ruminal ciliate protozoal populations in cattle fed medium- or high-concentrate barley-based diets. J. Anim. Sci. 79:515-524. 
Huntington, G. B. 1989. Hepatic urea synthesis and site and rate of urea removal from blood of beef steers fed alfalfa hay or a high concentrate diet. Can. J. Anim. Sci. 69:215-223.

Huntington, G. B. 1997. Starch utilization by ruminants: From basics to the bunk. J. Anim. Sci. 75:852-867.

Huntington, G. B., and S. L. Archibeque. 1999. Practical aspects of urea and ammonia metabolism in ruminants. Proc. Am. Soc. Anim. Sci. http://www.asas.org/symposia/1998-1999.htm Accessed May 2, 2007.

Jenkins, T. C. 1993. Lipid metabolism in the rumen. J. Dairy Sci. $76: 3851-3863$.

Jouany, J. P. 1996. Effect of rumen protozoa on nitrogen utilization by ruminants. J. Nutr. 126:1335S-1346S.

Kennedy, P. M., and L. P. Milligan. 1980. The degradation and utilization of endogenous urea in the gastrointestinal tract of ruminants: A review. Can. J. Anim. Sci. 60:205-221.

Kiran, D., and T. Mutsvangwa. 2007. Effects of barley grain processing and dietary ruminally degradable protein on urea nitrogen recycling and nitrogen metabolism in growing lambs. J. Anim. Sci. 85:3391-3399.

Lapierre, H., and G. E. Lobley. 2001. Nitrogen recycling in the ruminant: A review. J. Dairy Sci. 84(E Suppl.):E223-E236.

Lobley, G. E., D. M. Bremner, and G. Zuur. 2000. Effects of diet quality on urea fates in sheep as assessed by refined, non-invasive $\left[{ }^{15} \mathrm{~N}^{15} \mathrm{~N}\right]$ urea kinetics. Br. J. Nutr. 84:459-468.

Marini, J. C., J. M. Klein, J. M. Sands, and M. E. Van Amburgh. 2004. Effect of intake on nitrogen recycling and urea transporter abundance in lambs. J. Anim. Sci. 82:1157-1164.

Marini, J. C., and M. E. Van Amburgh. 2003. Nitrogen metabolism and recycling in Holstein heifers. J. Anim. Sci. 81:545-552.

Marsh, W. H., B. Fingerhunt, and E. Kirsch. 1957. Determination of urea $\mathrm{N}$ with the diacetyl method and an automatic dialyzing apparatus. Am. J. Clin. Pathol. 28:681-688.

NRC. 2001. Nutrient Requirements of Dairy Cattle. 7th rev. ed. Natl. Acad. Press, Washington, DC.

Oh, Y. G., K. H. Kim, J. H. Kim, J. J. Choung, and D. G. Chamberlain. 1999. The effect of the form of nitrogen in the diet on ruminal fermentation and the yield of microbial protein in sheep consuming diets of grass silage supplemented with starch or sucrose. Anim. Feed Sci. Technol. 78:227-237.

Oldick, B. S., and J. L. Firkins. 2000. Effects of degree of fat saturation on fiber digestion and microbial protein synthesis when diets are fed twelve times daily. J. Anim. Sci. 78:2412-2420.

Onetti, S. G., R. D. Shaver, M. A. McGuire, D. L. Palmquist, and R. R. Grummer. 2002. Effect of supplemental tallow on performance of dairy cows fed diets with different corn silage:alfalfa silage ratios. J. Dairy Sci. 85:632-641.

Ørskov, E. R., C. Fraser, V. C. Mason, and S. O. Mann. 1970. Influence of starch digestion in the large intestine of sheep on caecal fermentation, caecal microflora and faecal nitrogen excretion. Br. J. Nutr. 24:671.

Pantoja, J., J. L. Firkins, M. L. Eastridge, and B. L. Hull. 1994. Effects of fat saturation and source of fiber on site of nutrient digestion and milk production by lactating dairy cows. J. Dairy Sci. 77:2341-2356

Penner, G. B., K. A. Beauchemin, and T. Mutsvangwa. 2006. An evaluation of the accuracy and precision of a stand-alone submersible continuous ruminal $\mathrm{pH}$ measurement system. J. Dairy Sci. 89:2132-2140.

Qui, X., M. L. Eastridge, and J. L. Firkins. 2004. Effects of dry matter intake, addition of buffer, and source of fat on duodenal flow and concentration of conjugated linoleic acid and trans-11 C18:1 in milk. J. Dairy Sci. 87:4278-4286.

Raes, K., S. De Smet, and D. Demeyer. 2004. Effect of dietary fatty acids on incorporation of long chain polyunsaturated fatty acids and conjugated linoleic acid in lamb, beef and pork meat; a review. Anim. Feed Sci. Technol. 113:199-221.

Rémond, D., J. P. Chaise, E. Delval, and C. Poncet. 1993. Net flux of metabolites across the ruminal wall of sheep fed twice a day with orchardgrass hay. J. Anim. Sci. 71:2529-2538.

Rémond, D., F. Meschy, and R. Boivin. 1996. Metabolites, water and mineral exchanges cross the rumen wall: Mechanisms and regulation. Ann. Zootech. 45:97-119.

Russell, J. B., and D. B. Wilson. 1996. Why are ruminal cellulolytic bacteria unable to digest cellulose at low $\mathrm{pH}$ ? J. Dairy Sci. 79:1503-1509.

SAS Institute. 2004. SAS/STAT 9.1 User's Guide. SAS Institute Inc., Cary, NC.

Satter, L. G., and L. L. Slyter. 1974. Effect of ammonia concentration on rumen microbial protein production in vitro. Br. J. Nutr. 32:199-208.

Schauff, D. J., J. P. Elliott, J. H. Clark, and J. K. Drackley. 1992 Effects of feeding lactating dairy cows diets containing whole soybeans and tallow. J. Dairy Sci. 75:1923-1935.

Spanghero, M., and Z. M. Kowalski. 1997. Critical analysis of N balance experiments with lactating cows. Livest. Prod. Sci. $52: 113-122$.

Stern, M. D., G. A. Varga, J. H. Clark, J. L. Firkins, J. T. Huber, and D. L. Palmquist. 1994. Evaluation of chemical and physical properties of feeds that affect protein metabolism in the rumen. J. Dairy Sci. 77:2762-2786.

Theurer, C. B., G. B. Huntington, J. T. Huber, R. S. Swingle, and J. A. Moore. 2002. Net absorption and utilization of nitrogenous compounds across ruminal, intestinal, and hepatic tissues of growing beef steers fed dry-rolled or steam-flaked sorghum grain. J. Anim. Sci. 80:525-532.

Tyrrell, H. F., and J. T. Reid. 1965. Prediction of the energy value of cow's milk. J. Dairy Sci. 48:1215-1223.

Van Nevel, C. J., and D. I. Demeyer. 1996. Influence of $\mathrm{pH}$ on lipolysis and biohydrogenation of soybean oil by rumen contents in vitro. Rep. Nutr. Dev. 36:53-63.

Van Soest, P. J. 1994. Function of the ruminant forestomach. Pages 230-252 in Nutritional Ecology of the Ruminant. 2nd ed. Cornell University Press, Ithaca, NY.

Van Soest, P. J., J. B. Robertson, and B. A. Lewis. 1991. Methods for dietary fiber, neutral detergent fiber and non-starch polysaccharides (NSP) in relation to animal nutrition. J. Dairy Sci. 74:3583-3597.

Wang, Z., and L. A. Goonewardene. 2004. The use of MIXED models in the analysis of animal experiments with repeated measures data. Can. J. Anim. Sci. 84:1-11.

Ward, A. T., K. M. Wittenberg, and R. Przybylski. 2002. Bovine milk fatty acid profiles produced by feeding diets containing solin, flax and canola. J. Dairy Sci. 85:1191-1196.

Yang, W. Z., K. A. Beauchemin, and L. M. Rode. 2000. Effects of barley grain processing on extent of digestion and milk production of lactating cows. J. Dairy Sci. 83:554-568.

Yang, W. Z., K. A. Beauchemin, and L. M. Rode. 2001. Effects of grain processing, forage to concentrate ratio, and forage particle size on rumen $\mathrm{pH}$ and extent of digestion by lactating dairy cows. J. Dairy Sci. 84:2203-2216. 